\title{
SENSITIVITY OF THE MARINE BENTHIC COPEPOD TISBE BIMINIENSIS (COPEPODA, HARPACTICOIDA) TO POTASSIUM DICHROMATE AND SEDIMENT PARTICLE SIZE
}

\author{
Cristiane M. V. Araújo-Castro ${ }^{\text {, Lilia P. Souza-Santos }}{ }^{\text {, Anny Gabrielle A .G. Torreiro }}{ }^{I}$ \\ and Karina S. Garcia ${ }^{2}$ \\ ${ }^{1}$ Universidade Federal de Pernambuco - Departamento de Oceanografia, CTG \\ (Arquitetura s/n, Cidade Universitária 50670-901, Recife, PE, Brasil) \\ crisacastro@yahoo.com.broulpss@ufpe.br \\ ${ }^{2}$ Universidade Federal da Bahia - Instituto de Geociências \\ (Rua Barão de Geremoabo, s/n, sala 305 A1, Federação, 40170-290 Salvador, BA, Brasil)
}

\section{A B S T R A C T}

For the future use of the marine benthic copepod Tisbe biminiensis in solid-phase sediment toxicological bioassays, the present study investigated the effect of muddy sediment from the Maracaípe estuary (northeastern Brazil), sediment particle size and the reference toxicant potassium dichromate on the species. Muddy sediment from Maracaípe can be used as control sediment, since it does not interfere in the copepod life-cycle and has metal contamination levels that are unlikely to produce any detrimental biological effects on benthic invertebrates. Neither survival nor fecundity was affected by grain size, suggesting that this species can be used with any kind of sediment from muddy to sandy. The sensitivity of $T$. biminiensis to $\mathrm{K}_{2} \mathrm{Cr}_{2} \mathrm{O}_{7}$ in acute tests was similar to that of other organisms. The $\mathrm{LC}_{50}$ (lethal concentration to $50 \%$ of the test organisms) medium values for $T$. biminiensis were 7.51, 4.68 and $3.19 \mathrm{mg} \mathrm{L}^{-1}$ for $\mathrm{Cr}$ in 48,72 and $96 \mathrm{~h}$, respectively. These results suggest that $T$. biminiensis is a promising organism for use in solid-phase sediment toxicity assessments.

\section{RESUMO}

Visando o uso futuro do copépodo marinho bentônico Tisbe biminiensis em bioensaios toxicológicos de sedimentos na fase sólida, o presente estudo investigou o efeito do sedimento lamoso do estuário de Maracaípe (Nordeste do Brasil). Foram considerados a granolometria e o tóxico de referência dicromato de potássio sobre a espécie. O sedimento lamoso de Maracaípe pode ser usado como controle, uma vez que não interfere no ciclo de vida do copépodo e possui níveis de contaminação de metais que não causariam efeitos biológicos em invertebrados bentônicos. Nem a sobrevivência ou fecundidade foi afetada pelo tamanho do grão, sugerindo que esta espécie pode ser usada com qualquer tipo de sedimento, de lama a areia. A sensibilidade de T. biminiensis ao $\mathrm{K}_{2} \mathrm{Cr}_{2} \mathrm{O}_{7}$ em testes agudos foi similar a de outros organismos. Os valores de $\mathrm{CL}_{50}$ (concentração letal a $50 \%$ dos organismos) para T. biminiensis foram em média 7,51, 4,68 e $3,19 \mathrm{mg} \mathrm{L}^{-1}$ para o $\mathrm{Cr}$ em 48, $72 \mathrm{e}$ $96 \mathrm{~h}$, respectivamente. Estes resultados sugerem que T. biminiensis é um organismo promissor para uso em avaliações de toxicidade com a fase sólida do sedimento.

Descriptors: Toxicity, Meiofauna, Toxicity test, Potassium dichromate, Sediment grain size.

Descritores: Toxicidade, Meiofauna, Testes de toxicidade, Dicromaro de potássio, Granulometria.

\section{INTRODUCTION}

The highest concentrations of contaminants occur in estuarine and shallow coastal marine systems, as these environments are subject to considerable anthropogenic impact from both point and nonpoint sources. This potentially dangerous anthropogenic input is typically associated with accelerated human population growth, the development of coastal areas, agricultural, industrial and municipal discharge as well as commercial and recreational activities, with major impact at the community and ecosystem level (KENNISH, 1997; NIPPER, 2000). Sediments are known to effectively sequester hydrophobic chemical pollutants such as heavy metals and organic pollutants entering bodies of water (McCREADY et al., 2006). Estuaries are the ultimate repository for many pollutants and act as a temporary or long-term storage facility for natural and anthropogenic organic matter 
from land-based sources. Pollutants may persist in this system and/or become bioavailable to the water column (KENNISH, 1997; McCREADY et al., 2006). Contaminants can lead to the lethality or sub-lethality of organisms in this environment.

In Brazil, a federal law that regulates the release of new formulations of agrochemicals and new legislation for the disposal of dredged material (CONAMA Resolution No. 344, 2004, www.mma.gov.br/conama) require ecotoxicological assays for the management of bodies of water. The new legislation (CONAMA, 2004) establishes sediment quality criteria based on sediment quality guidelines (SQGs) developed in the United States and Canada. Although generic guidelines are frequently considered the best immediately available option, the search for ecologically realistic tests with native species and the field validation of international guidelines is recommended. Thus, academia and environmental agencies have developed adaptations of international toxicity testing methods in recent decades using native species (MELO; NIPPER, 2007).

In Brazil, crustacean species used for marine solid-phase sediment toxicity assessments include the amphipod (Tiburonella viscana), the tanaid (Kalliapseudis schubartii) and postlarvae of the shrimp (Litopenaeus sp., Penaeus paulensis and $P$. schmitti). However, methodological tests measuring a variety of endpoints and species are still necessary in order to obtain sufficient data for producing national sediment quality criteria or guidelines (MELO; NIPPER, 2007). Lotufo and Abessa (2002) have recommended the use of copepods for sediment toxicity tests.

Meiofauna species, particularly harpacticoid copepods, have been successfully used as indicators of sediment contamination and toxicity in controlled laboratory experiments (COULL; CHANDLER, 1992). The short copepod life cycle facilitates the determination of life-history-related endpoints, so several copepod species have been used successfully in toxicity tests.

Harpacticoid copepods of the genus Tisbe are particularly useful as bioassay organisms due to their high abundance in sediments, wide geographic distribution, short life cycles and amenability to laboratory cultures and handling (POUNDS et al., 2002). Tisbe battagliai is an internationally recognized test species for assessing water and sediment quality and, more importantly, is suitable for toxicity identification evaluation (TIE) (THOMAS et al., 2003). The ISO 14669 (1999) has standardized a protocol to evaluate water quality through the acute lethal toxicity in three copepod species (including Tisbe battagliai) in the copepodit stage.

Tisbe biminiensis Volkmann-Rocco 1973 possesses one of the highest exponential rates of population increase $(r)$ obtained for a meiobenthic copepod. It has a short generation time and high reproductive potential (PINTO et al., 2001; SOUZASANTOS et al., 2006). It is easily cultured under laboratory conditions; requires low sample volumes; does not need a large amount of space for cultivation; and has an easily observable lethal endpoint. Moreover, due to its epibenthic habits, it may be exposed to both sediment and water samples. This makes $T$. biminiensis a promising test organism for sediment toxicological assessments.

Therefore, the aim of the present study was to evaluate the acute tolerance of the copepod Tisbe biminiensis to potassium dichromate as a reference toxicant and the influence of sediment particle size on lethal and sub-lethal endpoints during sediment bioassays, which are pre-requisits for the future use of this species in solid-phase sediment toxicity tests.

\section{Materials And Methods}

Collection of Tisbe biminiensis for Cultivation

Tisbe biminiensis is an epibenthic harpacticoid copepod. The species was collected from the intertidal area of the sandy beach known as Farol Beach in Olinda, Pernambuco (NE Brazil). This beach is located in an urban area and is subject to high amounts of organic input from urban sewage. A sample of sand containing stranded seaweed was collected and taken to the laboratory. The seaweed was washed with filtered seawater and this seawater was placed with the sand in an aquarium for one week. Ovigerous female copepods were then taken from the aquarium, observed under the stereomicroscope and isolated to be reared. Tisbe biminiensis is very large and conspicuous in comparison with the others present on this beach. The females were individually placed in glass vessels containing filtered seawater and microalgae (diatoms) until new adults emerged. Some adults were then removed from each group for identification under the microscope. All groups identified as Tisbe biminiensis were joined together to assure genetic variability.

\section{Copepod Cultivation}

Tisbe biminiensis was cultivated in a substratefree medium represented by $500 \mathrm{~mL}$ vessels with seawater filtering $\left(25\right.$ and $3 \mu \mathrm{m} \mathrm{CUNO}^{\circledR}$ in sequential filtration) and salinity of $35 \pm 2$. Cultures were maintained in a climate-controlled room with the temperature maintained at between 25 and $27^{\circ} \mathrm{C}$ and a 
12-h dark/light photoperiod. Basic commercial fish food (All Plus ${ }^{\circledR}$ ) and diatoms (Thalassiosira fluviatilis or Phaeodactylum tricornutum) were offered to the copepods once a week. The water was completely changed once a week, passing the entire content of the plastic vessels through a $64-\mu \mathrm{m}$ sieve. The organisms retained in the sieve were transferred to clean vessels with $500 \mathrm{~mL}$ of filtered seawater, $20 \mathrm{~mL}$ of algal suspension and $100 \mathrm{mg}$ of fish food (SOUZASANTOS et al., 2006). Before every toxicity test, whenever a large number of ovigerous females were required, the volume of the cultures was increased to 5 $\mathrm{L}$, starting from $500 \mathrm{~mL}$ cultivation.

\section{Algal Culture}

Tisbe biminiensis developed better when fed with diatoms than with flagellates (PINTO et al., 2001). Thus, two diatom species (Thalassiosira fluviatilis and Phaeodactylum tricornutum) were used in the present study. Microalgae were cultivated in $f / 2$ medium (GUILLARD, 1975). For the preparation of the medium, tris- $\mathrm{HCl}$ buffer $(\mathrm{pH}$ 7.7) and $\mathrm{f} / 2$ nutrient stock were added to natural filtered seawater $(35 \pm 1 \%$ ) before sterilization in an autoclave. The $\mathrm{f} / 2$ vitamin solution (biotin, B12 and thiamine) was sterilized through filtration $(0.2 \mu \mathrm{m})$ and added to the medium just prior to algal inoculation. The algal cultures were incubated at room temperature $\left(26 \pm 1^{\circ} \mathrm{C}\right)$ with a 12 -h light/dark photoperiod. The concentration of microalgae was expressed as units of chlorophyll- $a$ ( $\mu \mathrm{g} \mathrm{Chl-a} \mathrm{mL} L^{-1}$ ).

\section{Female Cultivation for the Test}

The age of the first brood of $T$. biminiensis ranged from 7.6 to 10.8 days and total lifespan of $T$. biminiensis females ranged from 29 to 32.9 days (PINTO et al., 2001). To minimize natural mortality, 12 day-old ovigerous females were used in the tests. To obtain fixed-age females, main stock copepods were poured through $250-\mu \mathrm{m}$ sieves and organisms retained on the sieve were transferred to $20 \mathrm{~L}$ vessels containing $5 \mathrm{~L}$ of filtered seawater and food 13 days prior to the start of a test. After $24 \mathrm{~h}$, the copepod group was poured through the same sieve and adults were transferred to another vessel. Water renewal and feeding were performed twice a week. After 12 days, ovigerous females were collected for use in the test. When ovigerous females were very abundant in the culture before 12 days, younger females could also be used.

Testing the Presence of Muddy Sediment

The Tisbe biminiensis used in the present study was collected on a sandy beach, but in the laboratory, they grow as well in substrate-free media as in a sandy substrate (SOUZA-SANTOS et al., 2006). Thus, testing was performed to evaluate the behaviour of this copepod in muddy sediment. Groups of 10 ovigerous copepod females were submitted to two treatments: one with muddy sediment and $20 \mathrm{~mL}$ of the diatom suspension $\left(0.2 \mu \mathrm{g} \mathrm{Chl}-\mathrm{a} \mathrm{mL} \mathrm{m}^{-1}\right)$ and the other only with the diatom suspension. The experiments with the sediment followed the procedures recommended by Lotufo and Abessa (2002), who indicate the use of sieving to remove sand, vegetable debris, other fragments and possible predators from the sediment.

The muddy sediment was collected at low tide from the top $2 \mathrm{~cm}$ of the Maracaípe Estuary (S 08 32'21.8" W 35'00'14.5”), a well-preserved mangrove area far from urban centers and with a very small drainage basin. In the laboratory, the wet sediment (200 to $300 \mathrm{~g}$ ) was poured through a $63 \mu \mathrm{m}$ sieve with a small volume of filtered seawater and left to settle overnight at $4{ }^{\circ} \mathrm{C}$ in glass containers. The next day, the supernatant was removed through aspiration and $2 \mathrm{~g}$ of the sediment, which was the minimum amount necessary to form a $0.5-\mathrm{cm}$ layer on the bottom, was placed in each test container. The container used in the bioassays was a $40-\mathrm{mL}$ glass vessel with a plastic stopper $(4.5 \mathrm{~cm} \varnothing$ and $5 \mathrm{~cm}$ height). Twenty milliliters of the diatom suspension $\left(0.2 \mu \mathrm{g}\right.$ Chl-a $\left.\mathrm{mL}^{-1}\right)$ was then added to each test container and the entire test system was incubated at $25^{\circ} \mathrm{C}$, with a $12: 12 \mathrm{~h}$ light/dark photoperiod. There were 5 replicates for each treatment. After $24 \mathrm{~h}$, ten ovigerous females were placed into each test container. The experiment lasted seven days, which was a sufficient period to observe both mortality (lethal effect) and fecundity (sub-lethal effect). Every other day, $1 \mathrm{~mL}$ of concentrated diatom suspension was added. At the start and end of the experiments, $\mathrm{pH}$, oxygen concentration and salinity were determined. After 7 days, females and offspring were collected by gently pouring the control sediment through a $63-\mu \mathrm{m}$ sieve. After checking for live females, samples were stained with Rose-Bengal and fixed with formaldehyde (4\%). Stained individuals were counted using a stereomicroscope.

Mean mortality and fecundity were compared using ANOVA after testing for the normality of the data (Kolmogorov-Smirnof test) and variance homogeneity (Bartlett test). The Kruskal-Wallis nonparametric test was used when the data were not normal or variances were not homogeneous. The Tukey test was used to identify significant differences between means (pairwise comparisons). The significance level was set at 0.05 . An overview of the experiments is given in Table 1. 
Table 1. Experimental conditions of the tests undertaken using the Tisbe biminiensis.

\begin{tabular}{|c|c|c|c|}
\hline & \multicolumn{3}{|c|}{ Experiments } \\
\hline & $\begin{array}{l}\text { Testing the presence } \\
\text { of muddy sediment }\end{array}$ & Testing different sediment grain size & $\begin{array}{c}\text { Acute toxicity of potassium } \\
\text { dichromate }\end{array}$ \\
\hline Treatments & $\begin{array}{l}\text { With and without } \\
\text { sediment }\end{array}$ & $\begin{array}{c}\text { GR0 }=\text { only water } \\
\text { GR1 = sediment }<63 \mu \mathrm{m} \\
\text { GR2 }=\text { sediment }>63 \mu \mathrm{m} \text { and }<125 \mu \mathrm{m} \\
\text { GR3 }=\text { sediment }>125 \mu \mathrm{m} \text { and }<250 \mu \mathrm{m} \\
\text { GR4 }=\text { sediment }>250 \mu \mathrm{m} \text { and }<2 \mathrm{~mm}\end{array}$ & $\begin{array}{l}0 \text { (control), 5, 10, 15, } 20 \\
\text { and } 25 \mathrm{mg} \mathrm{K}_{2} \mathrm{Cr}_{2} \mathrm{O}_{7} \mathrm{~L}^{-1}\end{array}$ \\
\hline Replicates & 5 & 5 & 5 \\
\hline Food & Diatom suspension & Diatom suspension & Diatom suspension \\
\hline $\begin{array}{l}\text { Number of } \\
\text { organisms per } \\
\text { chamber }\end{array}$ & 10 ovigerous females & 10 ovigerous females & 10 ovigerous females \\
\hline Temperature & $25^{\circ} \mathrm{C}$ & $25^{\circ} \mathrm{C}$ & $25^{\circ} \mathrm{C}$ \\
\hline Light regime & 12/12 light/dark & 12/12 light/dark & 12/12 light/dark \\
\hline salinity & $34 \pm 1$ & $34 \pm 1$ & $34 \pm 1$ \\
\hline Addition of food & Every other day & Every other day & Without addition of food \\
\hline $\begin{array}{l}\text { Duration of } \\
\text { experiment }\end{array}$ & 10 and 7 days & 7 days & $96 \mathrm{~h}$ \\
\hline
\end{tabular}

Testing Different Sediment Grain Sizes

To study the effect of sediment grain size on the survival, fecundity and development of $T$. biminiensis, an experiment was performed with four grain size fractions (Table 1) and a control (without sediment). These fractions were obtained by sieving sediment from the Maracaípe Estuary through different mesh sizes $(250,125$ and $63 \mu \mathrm{m})$.

In these experiments, 10 ovigerous females were placed in each test container $24 \mathrm{~h}$ after the introduction of sediment and diatom suspension. The experiments were performed in the same manner as in the previous test (Table 1).

\section{Acute Toxicity of Potassium Dichromate}

Bioassays with reference substances are necessary for the evaluation of the sensitivity of the animal group used in toxicological tests. A minimum of five tests are necessary to establish the repeatability of results (ISO 14669, 1999; U.S. EPA, 1988). In order to evaluate the sensitivity of ovigerous $T$. biminiensis females to potassium dichromate $\left(\mathrm{K}_{2} \mathrm{Cr}_{2} \mathrm{O}_{7}\right)$, twelve experiments were performed to determine the 48, 72 and 96-h LC 50 (Table 1).

Each container received 10 ovigerous females and $20 \mathrm{~mL}$ of the diatom suspension with five different concentrations of potassium dichromate $(5$, $10,15,20$ and $25 \mathrm{mg} \mathrm{L}^{-1}$; established in a preliminary test) and a control (without potassium dichromate). There were 5 replicates for each concentration. After the introduction of the females, all replicates were incubated at $25^{\circ} \mathrm{C}$ and a $12: 12 \mathrm{~h}$ light/dark photoperiod. At the start and end of the experiments, $\mathrm{pH}$, salinity and the oxygen concentration were determined.

Observations were made every $24 \mathrm{~h}$ and dead females were removed. The lethal concentration acrescentar killing $50 \%\left(\mathrm{LC}_{50}\right)$ of organisms in 48 , 72 and $96 \mathrm{~h}$ was estimated using the Trimmed Spearman-Karber method with Abbot's correction (HAMILTON et al., 1977).

\section{Determination of AVS and Metal Concentration in the Maracaípe Sediment}

The determination of metal concentrations $(\mathrm{Cd}$, $\mathrm{Cr}, \mathrm{Cu}, \mathrm{Ni}, \mathrm{Pb}$ and $\mathrm{Zn}$ ) in sediment samples followed the methodology of Allen et al. (1993), as described by Silverio (1999). In this method, $3 \mathrm{~g}$ of wet sediment was reacted with $20 \mathrm{ml}$ of $\mathrm{HCl} 6 \mathrm{~mol} . \mathrm{L}^{-1}$ in a cold, $\mathrm{N}_{2}$ atmosphere. The final $\mathrm{HCl}$ concentration in the balloon was $2 \mathrm{~mol}$. $\mathrm{L}^{-1}$. The metals were determined through Flame Atomic Absorption Spectrometry (FAAS) after being filtered in quantitative paper and calibrated with $50 \mathrm{ml}$ de-ionized water.

\section{Results}

Testing the Presence of Muddy Sediment

During the test, $T$. biminiensis adults and offspring were not observed swimming in containers with sediment, indicating that this species has a strong relationship with the sediment. 
The adult mortality (Student's $t=-0.2769, p=$ 0.7941 ) and female fecundity (Student's $t=-1.8332, p$ $=0.1164)$ were not statistically different as between containers with and without muddy sediment (Fig. 1). The mortality was below $10 \%$ in both treatments. At the end of one week, ten $T$. biminiensis females produced a mean $( \pm$ SD) of $236( \pm 145)$ and $206( \pm 74)$ offspring in the treatments with and without muddy sediment, respectively.

The metal concentrations in the muddy sediment from the Maracaípe Estuary are presented in Table 2 . For most metals, the concentrations were very low and undetectable.

\section{Testing Different Sediment Grain Sizes}

In relation to grain size, neither survival (ANOVA, $F=2.159 . p=0.1204$ ), number of nauplii (ANOVA, $F=2.630 . p=0.0733$ ), number of copepodites (ANOVA, $F=2.634 . p=0.0730$ ) nor fecundity (ANOVA, $F=2.707 . p=0.0677$ ) were significantly different between treatments (Fig. 2). Survival was higher than $90 \%$ and fecundity was above 150 individuals in all treatments.

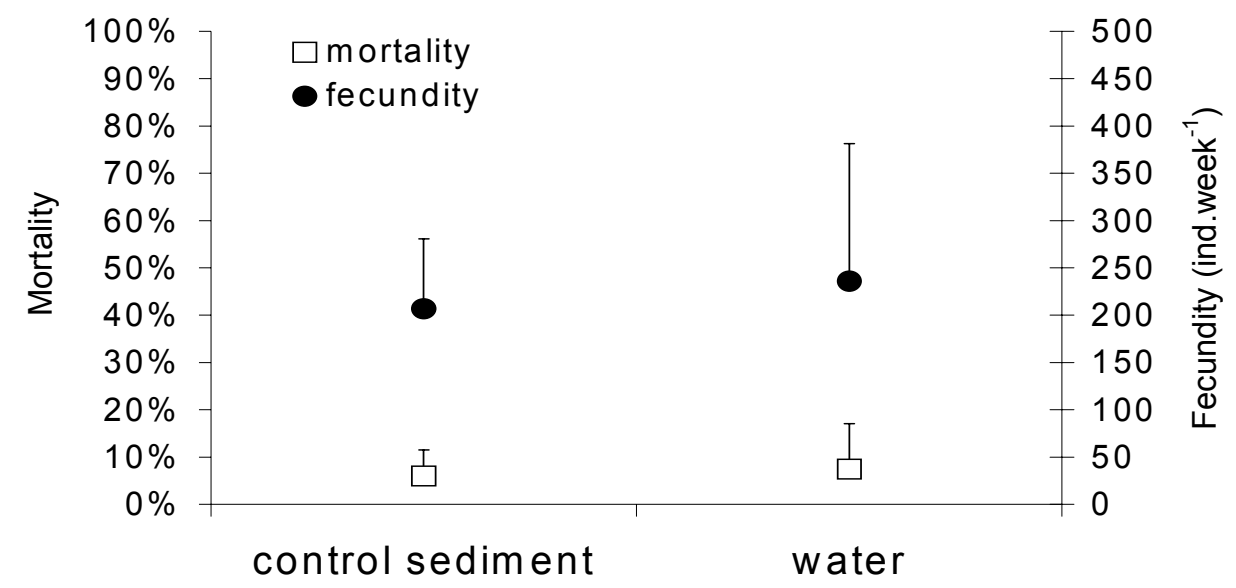

Fig. 1. Mortality and fecundity (means $\pm 1 \mathrm{SD}$ ) of Tisbe biminiensis females exposed to the control sediment and in seawater for 7 days. $n=5$.

Table 2. Metal concentrations $\left(\mu \mathrm{g} \cdot \mathrm{g}^{-1}\right)$ estimated in the sediment samples of Maracaípe estuary collected on March 2007 compared to effects-range sediment guidelines by NOAA and Long et al. (1995).

\begin{tabular}{|c|c|c|c|c|c|c|}
\hline \multirow[t]{2}{*}{ Metals } & \multirow{2}{*}{$\begin{array}{l}\text { Control sediment } \\
\text { Mean } \pm \text { SD }(\mu \mathrm{g} / \mathrm{g})\end{array}$} & \multicolumn{3}{|c|}{$\begin{array}{l}\text { NOAA } \\
(\mu \mathrm{g} / \mathrm{g})\end{array}$} & \multicolumn{2}{|c|}{ Long et al. (1995) $(\mu \mathrm{g} / \mathrm{g})$} \\
\hline & & TEL & PEL & $\mathrm{Bgd}$ & ERL & ERM \\
\hline $\mathrm{Cd}$ & n.d. & 0.676 & 4.21 & & 1.2 & 9.6 \\
\hline $\mathrm{Cr}$ & $3.76 \pm 1.05$ & 52.3 & 160 & 37 & 81 & 370 \\
\hline $\mathrm{Cu}$ & $1.10 \pm 1.77$ & 18.7 & 108.2 & 17 & 34 & 270 \\
\hline $\mathrm{Ni}$ & $1.84 \pm 0.27$ & 15.9 & 42.8 & 13 & 20.9 & 51.6 \\
\hline $\mathrm{Pb}$ & $1.84 \pm 3.07$ & 30.2 & 112.2 & 16 & 46.7 & 218 \\
\hline $\mathrm{Zn}$ & $13.21 \pm 2.95$ & 124 & 271 & 48 & 150 & 410 \\
\hline
\end{tabular}

n.d. - not detectable; TEL - Threshold Effect Level; PEL - Probable Effects Level; Bgd - Background; ERL - Effects Range-Low; ERM - Effects Range Median. 


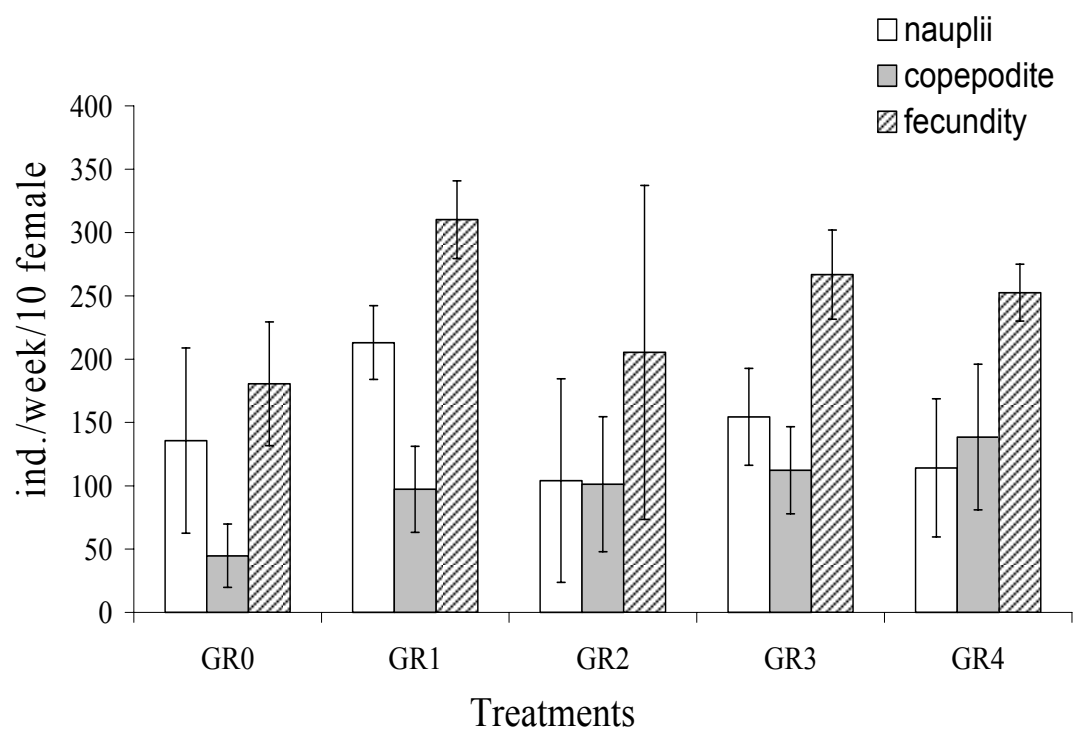

Fig. 2. Mean nauplii number, copepodite number and fecundity of Tisbe biminiensis obtained with different grain sizes (GR0 = only seawater; GR1 $=$ less than $63 \mu \mathrm{m}$; GR2 = greater than $63 \mu \mathrm{m}$ and less than $125 \mu \mathrm{m}$; GR3 = greater than $125 \mu \mathrm{m}$ and less than 250 $\mu \mathrm{m}$; and GR4 $=$ greater than $250 \mu \mathrm{m}$ and less than $2 \mathrm{~mm}$ ).

\section{Acute Toxicity of Potassium Dichromate}

T. biminiensis was sensitive to the reference substance. Table 3 displays the means \pm standard deviation of acute toxicity observed at different time periods at $25^{\circ} \mathrm{C}$ after 12 tests. Little variability was observed between the replicates of the bioassay with potassium dichromate, resulting in low coefficient variation.

\section{Discussion}

The results of these experiments suggest that Tisbe biminiensis is a promising organism for use in solid-phase sediment toxicity tests. This species is as sensitive as other test organisms used for the assessment of sediment toxicity (Table 4) and was highly independent in relation to sediment particle grain size. This study is the first step in an attempt to develop a simple standardized laboratory toxicity test with a tropical benthic copepod to evaluate estuarine and marine sediments.

In developing a marine-estuarine sediment bioassay protocol, a number of properties are desirable, such as a high survival rate under control conditions; occupation of microhabitat, preferably below the sediment-water interface to ensure maximum and consistent exposure to sediment contaminants; a broad geographic range to enhance the breadth of its application as a test species; ease of collection, handling and maintenance in the laboratory; ecological importance in estuarine ecosystems; the ability to be cultured or year-round availability from the field; and low sensitivity to natural sediment variables, such as particle size and organic content, to allow a wide variety of sediment types to be tested (INGERSOLL, 1995).

In the present study, T. biminiensis demonstrated low sensitivity to different particle sizes, as no significant differences were found in its life cycle in relation to grain size. The muddy sediment did not interfere in the life cycle of the copepod, demonstrating that $T$. biminiensis collected from a sandy beach may be used as test organism in bioassays with this type of sediment. While some species of amphipods are tolerant to different grain sizes, e.g., Leptocheirus plumulosus (DeWITT et al., 1992), others may exhibit survival or growth reduction as a result of unsuitable sediment particle size distribution, e.g., Rhepoxynius abronius, Grandidiella japonica and Tiburonella viscana (MELO; NIPPER, 2007).

In relation to sensitivity to reference toxicants, the coefficient of variation for the $\mathrm{LC}_{50}$ recommended by Environment Canada (1992) is $30 \%$, and the coefficients observed in the present study were 10.8 , 26.8 and $17.9 \%$ (at 48, 72 and $96 \mathrm{~h}$, respectively) for $\mathrm{K}_{2} \mathrm{Cr}_{2} \mathrm{O}_{7}$ and $\mathrm{Cr}$, demonstrating that $T$. biminiensis sensitivity did not vary substantially between tests and remained below the recommended level. 
Table 3. Mean LC50 ( \pm standard deviation) and coefficient of variation (CV) in different period (48, 72 and $96 \mathrm{~h}$ ) of $\mathrm{K}_{2} \mathrm{Cr}_{2} \mathrm{O}_{7}$ and $\mathrm{Cr}$ for Tisbe biminiensis. $\mathrm{n}=12$.

\begin{tabular}{lccc}
\hline \hline \multicolumn{3}{c}{ CL50 mg L ${ }^{-1}( \pm \mathrm{SD})$} \\
\hline $\mathrm{K} 2 \mathrm{Cr} 2 \mathrm{O} 7$ & $48 \mathrm{~h}$ & $72 \mathrm{~h}$ & $96 \mathrm{~h}$ \\
$\mathrm{Cr}$ & $22.22( \pm 2.30)$ & $13.84( \pm 3.72)$ & $9.45( \pm 1.68)$ \\
\hline
\end{tabular}

Table 4. Median lethal concentrations (LC50) of $\mathrm{K}_{2} \mathrm{Cr}_{2} \mathrm{O}_{7}$ and $\mathrm{Cr}$ obtained with Tisbe biminiensis and others organisms.

\begin{tabular}{|c|c|c|c|c|c|}
\hline \multirow{2}{*}{ Species } & \multirow{2}{*}{ Duration } & \multirow{2}{*}{ Conditions } & \multicolumn{2}{|c|}{$\operatorname{LC50}\left(\mathrm{mg} \mathrm{L}^{-1}\right)$} & \multirow{2}{*}{ Reference } \\
\hline & & & $\mathrm{K} 2 \mathrm{Cr} 2 \mathrm{O} 7$ & $\mathrm{Cr}$ & \\
\hline \multicolumn{6}{|l|}{ Amphipod } \\
\hline Tiburonella viscana & $48 \mathrm{~h}$ & $25 \pm 2{ }^{\circ} \mathrm{C}$ & 11.217 & 3.79 & $\begin{array}{l}\text { Abessa; Sousa } \\
\text { (2003) }\end{array}$ \\
\hline Tiburonella viscana & $48 \mathrm{~h}$ & $25^{\circ} \mathrm{C}$ & & 5.85 & $\begin{array}{l}\text { Melo; Nipper } \\
\text { (2007) }\end{array}$ \\
\hline \multicolumn{6}{|l|}{ Shrimp } \\
\hline Palaemon elegans & $96 \mathrm{~h}$ & $16^{\circ} \mathrm{C}$ & 43.96 & 14.86 & $\begin{array}{c}\text { Lorenzon et al. } \\
\text { (2001) }\end{array}$ \\
\hline \multicolumn{6}{|l|}{ Copepod } \\
\hline Tisbe longicornis & $48 \mathrm{~h}$ & $20^{\circ} \mathrm{C}$ & 10 & 3.38 & $\begin{array}{l}\text { Larrain et al. } \\
\quad(1998)\end{array}$ \\
\hline Tisbe holoturiae & $48 \mathrm{~h}$ & $24{ }^{\circ} \mathrm{C}$ & & 16.12 & $\begin{array}{l}\text { Coull; Chandler } \\
\text { (1992) }\end{array}$ \\
\hline \multirow{2}{*}{ Tisbe biminiensis } & $48 \mathrm{~h}$ & $25^{\circ} \mathrm{C}$ & 21.61 & 7.51 & \multirow{2}{*}{ This study } \\
\hline & $96 \mathrm{~h}$ & $25^{\circ} \mathrm{C}$ & 10.77 & 3.19 & \\
\hline
\end{tabular}

Table 4 displays the $\mathrm{LC}_{50}$ of $T$. biminiensis and other organisms. T. biminiensis seems to be more resistant to $\mathrm{K}_{2} \mathrm{Cr}_{2} \mathrm{O}_{7}$ than Tiburonella viscana and Tisbe longicornis. However, it is more sensitive than T. Holothuriae and Palaemon elegans and is as sensitive as Tiburonella viscana. Thus, different organisms can respond differently to the same substance and $T$. biminiensis demonstrated both sensitivity and consistency in its response to this toxicant.

Bioassays with benthic copepods have been developed in several places in the world. The genus Tisbe has wide geographic distribution (VOLKMANN, 1979) and it has frequently been used in lethal and sub-lethal toxicity tests due to its easy maintenance in the laboratory, high sensitivity to toxins and ecological importance (SILVA et al., 2000).

$T$. biminiensis has a short life cycle, fast development, high reproductive potential and one of the highest rates of increase among harpacticoids in cultures (ARAÚJO-CASTRO; SOUZA-SANTOS, 2005; PINTO et al., 2001; SOUZA-SANTOS et al.,
2006). This species has been cultured under laboratory conditions since 1998 and has demonstrated its ability to reach high densities, thereby facilitating its use in toxicity tests. A single female $T$. biminiensis may produce up to nine broods during its life-time, with a mean 66.8 nauplii per brood. Females lay a new eggsac 2 days after nauplii are born (PINTO et al., 2001). Therefore, the high reproductive potential of $T$. biminiensis can facilitate the observation of sub-lethal effects.

Advanced age and inadequate food quality and quantity may cause high mortality and low fecundity in T. biminiensis (PINTO et al., 2001). Thus, bioassays require the use of $T$. biminiensis females with the same age (12 \pm 1 day) and the addition of food every other day in order to minimize the effects of these factors on mortality and fecundity. The duration of a bioassay must not be more than 7 days; otherwise the counting of stained females to estimate survival will be hampered due to offspring development.

The sediment from the Maracaípe Estuary used in the present study had low concentrations of 
heavy metals. According to Carreira (personal communication), this sediment has low HPA and aliphatic concentrations, $44.9 \mathrm{ng} \mathrm{g}^{-1}$ and $0.262 \mu \mathrm{g} \mathrm{g}^{-1}$, respectively. This low contaminant concentration and high survival and fecundity rates make the Maracaípe sediment a good control.

In conclusion, $T$. biminiensis demonstrated high tolerance to a wide range of sediment grain sizes. The species has moderate and relatively constant sensitivity to the reference substance sodium dichromate. It may therefore be suggested that this species has high potential for use in routine solidphase sediment toxicity tests using the procedures described here, although additional tests are required, such as the investigation of its tolerance to ammonia.

\section{ACKNOWLEDGEMENTS}

This study was supported by RELINE (Resíduos Líquidos do Nordeste). The first and third authors received financial support from the Conselho Nacional de Desenvolvimento Científico Tecnológico $(\mathrm{CNPq})$. The authors wish to thank S.O. Lourenço and Alfredo Galvez for the microalgal strains, and P.J.P. Santos, S. Neumann-Leitão, P.S.M. Carvalho, C. Medeiros-Limongi and the anonymous referees for their suggestions.

\section{REFERENCES}

ABESSA, D. M. S.; SOUZA, E. C. P. M. Sensitivity of the amphipod Tiburonella viscana (Platyischnopidae) to $\mathrm{K}_{2} \mathrm{Cr}_{2} \mathrm{O}_{7}$. Braz. Arch. Biol. Technol., v. 46, p. 53-55, 2003.

ALLEN, H. E.; EU, G.; DENG, B. Analysis Acid-volatile Sulfid (AVS) and simultaneously extracted metals (SEM) for the estimation of potential toxicity in aquatic sediments. Environ. Toxicol. Chem., v. 12, p. 1441 1453,1993

ARAÚJO-CASTRO, C. M. V.; SOUZA-SANTOS, L. P. Are the diatoms Navícula $\mathrm{sp}$. and Thalassiosita fluviatilis suitable to be fed to the benthic harpacticoid copepod Tisbe biminiensis? J. expl mar. Biol. Ecol., v. 327, p. $58-69,2005$

COULL, B. C.; CHANDLER, G. T. Pollution and meiofauna: Field, laboratory, and mesocosm studies. Oceanogr. mar. Biol. a. Rev., v. 30, p. 191-271, 1992.

DeWITT, T. H.; REDMOND, M. S.; SEWALL, J.E.; SWARTZ, R.C. Development of a chronic sediment toxicity test for marine benthic amphipods. Contribution USEPA/ERL-Narragansett, No. N$240,1992$.

ENVIRONMENT CANADA. Biological test method: acute test for sediment toxicity using marine or estuarine amphipods. Environment Canada, Ottawa, 1992. Report EPS 1/RM/26

GUILLARD, R. R. L. Culture of phytoplankton for feeding marine invertebrates. In: SMITH, W. L.; CHANLEY, M. H. (Eds). Culture of marine invertebrates animals. Plenum Press. N. Y., pp. 26-60. 1975.
HAMILTON, M. A., RUSSO, R. C., THURSTON, R. V. Trimmed Spearman-Karber Method for estimating median lethal concentrations in toxicity bioassay. Envir. Sci. Technol. v. 11, p. 714-719, 1977.

INGERSOLL, C.G. Sediment tests. In: RAND, G. M. (ED.). Fundamentals of aquatic toxicology: effects, environmental fate, and risk assessment. Washington: Taylor and Francis, 1995. p. 231-255.

ISO 14669 . Water quality - Determination of acute lethal toxicity to marine copepods (Copepoda, Crustacea) Geneva, Switzerland. First edition. 1999-04-01, 1999.

KENNISH, M.J. Pollution impacts on marine biotic communities. Marine Science Series. CRC Press., 1997, 308p.

LARRAIN, A.; SOTO, E.; SILVA, J.; BAY-SCHMITH, E. Sensitivity of the meiofaunal copepod Tisbe longicornis to $\mathrm{K}_{2} \mathrm{Cr}_{2} \mathrm{O}_{7}$ under varying temperature regimes. Bull. environ. Contamin. Toxicol., v. 61, p. 391-396, 1998.

LOTUFO, G. R.; ABESSA, D.M. S. Testes de toxicidade com sedimento total e água intersticial estuarinos utilizando copépodos bentônicos. In: NASCIMENTO, I. A.; SOUSA, E. C. P. M.; NIPPER, M. Métodos em ecotoxicologia marinha: aplicações para o Brasil. São Paulo, Artes Gráficas e Industriais, 2002. p. 151-162.

LORENZON, S.; FRANCESE, M.; SMITH, V.J.; FERRERO, E. A. Heavy metals affect the circulating haemocyte number in the shrimp Palaemon elegans. Fish Shellfish Immunol., , v. 11, p. 459-472, 2001.

McCREADY, S.; BIRCH, G.F.; LONG, E.R. Metallic and organic contaminants in sediments of Sydney Harbour, Australia and vicinity - A chemical dataset for evaluating sediment quality guidelines. Environ. Int., v. 32, p. 455-465, 2006.

MELO, S.L.R.; NIPPER, M. Sediment toxicity tests using the burrowing amphipod Tiburonella viscana (Amphipoda: Platyischnopidae). Ecotoxicol. Environ. Saf., v. 66, p. 412-420, 2007.

NIPPER, M. Current approaches and future directions for contaminant-related impact assessments in coastal environments: Brazilian perspective. Aquat. Ecosys. Health Mgmt., v. 3, p. 433-447, 2000.

PINTO, C. S. C.; SOUZA-SANTOS, L. P.; SANTOS, P. J. P. Development and population dynamics of Tisbe biminiensis (Copepoda: Harpacticoida) reared on different diets. Aquaculture, v. 198, p. 253-267, 2001.

POUNDS, N. A.; HUTCHINSON, T. H.; WILLIAMS, T. D.; WHITING, P.; DINAN, L. Assessment of putative endocrine disrupters in an in vivo crustacean assay and an in vitro insect assay. Mar. environ. Res., v. 54, p. 709-713, 2002.

SILVA, E. M.; CHASTINET, C. B. A.; NAVARRO, M. F. T.; BARROS, A. F.; CAVALCANTE, P.; MOTA, M. F. V. Utilização de ensaios de ecotoxicidade com Tisbe holothuriae (Copepoda: Harpacticoida) em programas de avaliação da toxicidade de efluentes complexos. In: ESPÍNDOLA, E. L .G.; PASCHOAL, C. M. R. B.; ROCHA, O.; BOHRER, M. B. C.; OLIVEIRA NETO, A.L. Ecotoxicologia: perspectivas para o século XXI. São Carlos: RIMA, 2000. p. 451-460.

SILVÉRIO, P.F. Partição, biodisponibilidade e toxidade de metais pesados a organismos bentônicos em sedimentos. São Carlos,. 78 f. Dissertação (Mestrado em Química) - Instituto de Química, Universidade Federal de São Carlos, São Carlos, SP, 1999. 
SOUZA-SANTOS, L.P.; PASTOR, J.M.O.; FERREIRA, N.G.; COSTA, W.M.; ARAÚJO-CASTRO, C.M.V.; SANTOS, P.J.P. Developing the harpacticoid copepod Tisbe biminiensis culture: testing for salinity tolerance, ration levels, presence of sediment and density dependent analyses. Aquat. Res., v. 37, p. 1516-1523, 2006.

THOMAS, K. V.; BARNARD, N.; COLLINS, K.;

EGGLETON, J. Toxicity characterization of sediment porewaters collected from UK estuaries using a Tisbe battagliai bioassay. Chemosphere, v. 53, p. 1105-1111, 2003.
U.S. EPA. Short term methods for estimating the chronic toxicity and effluents and receiving waters to marine and estuarine organisms. EPA/600/4-87/028, 1988.

VOLKMANN, B. Tisbe (Copepoda, Harpacticoida) species from Bermuda and zoogeographical considerations. Arch. Oceanogr. Limnol., v. 19, p. 1-76, 1979.

(Manuscript received 24 January 2008; revised 03 June 2008; accepted 15 August 2008) 